\title{
Accounting
}

\section{Corporate governance mechanism as income smoothing suppressor}

\author{
Alwan Sri Kustono ${ }^{a^{*}}$
}

${ }^{a}$ Accounting Department, University of Jember, Jln. Kalimantan no 37, East Java, Indonesia, 68121

\section{H R O N I C L E}

\begin{tabular}{l}
\hline Article history: \\
Received: December 18, 2020 \\
Received in revised format: \\
January 92021 \\
Accepted: January 11, 2021 \\
Available online: \\
January 11,2021 \\
\hline Keywords: \\
Income smoothing \\
Commissioners \\
Audit tenure \\
Agency theory \\
Earnings management
\end{tabular}

\section{Introduction}

The company implements earnings management practices with two objectives, namely informative and opportunistic. If the aim is to be efficient, it means management is designing an advantage to communicate personal information. The information relates to profitability prospects. Opportunistic motivation means that management reports earnings to maximize their interests. Management manipulates earnings to benefit itself. Motives for taxes, bonuses, debt covenants, or the avoidance of specific contracts generally drive opportunistic accounting engineering. If earnings management is opportunistic, earnings information can lead to wrong investment decisions for investors. In some cases, earnings management becomes out of control. Financial reports become misrepresentations and lead to misinformation for investors. Earnings management is an early indication of financial information (Dadbeh \& Mogharebi, 2013; Toumeh \& Yahya, 2019). Income smoothing is a form of earnings management carried out by management for several periods to present a stable earnings flow level. Income smoothing is a manager's effort to reduce earnings volatility in a certain period, especially to achieve the level of earnings expected by the market or analyst (C. Chen, Weng, \& Fan, 2016). The technique for smoothing the volatility of income is to save part of the income during good periods and increase the reported income when it does not meet expectations.

* Corresponding author. Tel.: +62-85258303999

E-mail address: alwankustono@gmail.com (A. S. Kustono) 
Income smoothing is more attractive than other earnings management research for two reasons. First, accounting literature defines income smoothing more precisely than other engineering forms, such as income-increasing, income-decreasing, a big bath, etc. Second, many studies successfully identify smoother and non-smoother companies (Bressan, de Souza, \& Bressan, 2017). Some researchers consider that the practice of income smoothing is immoral, fraudulent, and misleading by company management. Management has information asymmetry to indirectly increase company value through earnings management (Farichah, 2017). Investors can mistake the condition and prospects of a company because of their limitations and inability to observe the financial reporting process. As a result, the market sees this smoothing as an attempt to mislead shareholders and investors. Another opinion argues that income smoothing is management's effort to satisfy shareholders by reducing company risk (Al-Natsheh \& Al-Okdeh, 2020). Analysts consider companies that have a stable earnings flow are low volatility. Investors and creditors consider this type of company with a low risk of bankruptcy because they provide a more certain guarantee of future returns (Junianto \& Wisadha, 2014). Agency theory states that managers can prioritize the manager's wealth over maximizing the principal's welfare in the presence of asymmetric information. Accounting numbers often become base manager's bonuses, compensation, or promotions (Curvello, Rodrigues, \& Macedo, 2018; Linhares, Da Costa, \& Beiruth, 2018). In particular, they have more control over company information so that they have the opportunity to do earnings management. Agency costs can minimize these opportunities in the form of corporate governance. The corporate governance $(\mathrm{CG})$ mechanism includes supervision and auditing. If this mechanism is useful, it can suppress negative incentives for management. Several previous studies tested the CG mechanism using the board size of commissioners (COM), the independent commissioners (independent commissionaires), and the audit quality (El Guindy \& Basuony, 2018; Fawzi, 2015; Manukaji, 2018; Maswadeh, 2018; Mbobo \& Archibong, 2016; Mohamed \& Habib, 2013; Rusmin, 2014; Yang, Tan, \& Ding, 2017; Young, 2015).

Previous research related to income smoothing has shown inconsistent results, both in terms of significance or direction of influence. The effect of board size on income smoothing also remains a contradiction. The greater the number of board members, the higher the possibility for management to carry out earnings management. A large number of members of the board worsens coordination, so that it is ineffective. Another opinion states that the more commissioners there are, the greater the ability to reduce financial statement manipulation. The effect between board size and earnings management is negative, likewise with the existence of independent commissionaires. Some claim that independent commissionaires exert pressure to get management away from engineering financial statements. The others argue otherwise that independent commissionaires are not an effective mechanism for reducing the practices. The extent of the effectiveness of the board's role is still being debated. In general, the board's role effectiveness depended on board size and the existence of independent commissionaires. Frequently, audit quality is considered a substantial barrier to earnings management. Audit quality prevents firms from managing revenue through discretionary accruals. They can detect accruals that are not normal (Mohamed \& Habib, 2013; Reguera-Alvarado, de Fuentes, \& Laffarga, 2019). Income smoothing is an essential topic in accounting research because it analyzes management efforts in earnings management reports by exploiting accounting standards gaps (Wang \& Williams, 2011). Although income smoothing is not against the rules, it can be a tool to cover up dishonesty in management. If the financial statements contain engineered information, the reliability will decrease. Users of financial statements can make mistakes when making decisions based on engineered accounting numbers. Income smoothing is often an attempt to mislead shareholders and potential investors. Investors do not obtain accurate information about earnings to evaluate the returns and risks of their portfolios. The practice of income smoothing can end in the form of fraud. In the practice of income smoothing, the reported profit is sometimes higher than the profit it should be, and sometimes it is lower. A company may hide or withhold a portion of its current earnings for reporting in future periods when future earnings are below. The choice of action adapts to the market. Concealment or delay in revenue recognition can occur if higher reporting of future earnings is assumed to be very positive by the market (Kustono \& Valencia, 2017; Shu \& Thomas, 2019). The Indonesian capital market has different characteristics from the developed capital markets in the world. These differences in characteristics are mainly due to the high concentration of ownership and controlling shareholders' dominance. This difference may lead to different application of agency theory from developed countries. Based on this background, the research problem's formulation is: Do board size, independent commissionaires' size, and audit quality reduce income smoothing practices in Indonesia's manufacturing companies?

\section{Literature Review}

Agency theory states that a firm as a contract between the owner of the resource and the party entrusted with managing the resource. An agency relationship can arise when the principal assigns the agent to action and delegates decision-making authority to the agent. (Young, 2015). In an agency relationship, the principal wants the agent to act according to his interests. The agent's actions, policies, and strategic choices are the ultimate goal of maximizing his welfare. On the other hand, agents have their interests, and as a result, they can act contrary to the principal's interests. According to agency theory, a conflict of interest between management and principals influence earnings management. Managers can maximize their welfare by displacing or reducing the welfare of the principal. Managers may have a desire to improve company performance artificially. By making the company bigger, growing faster, or performing better, the manager's status will increase. The goal is to obtain salary increases, bonuses, positions, and increase job security from the threat of dismissal (Saksessia \& Firmansyah, 2020). 
Income smoothing is a management action that is an artificial engineering classification. To suppress engineering action, the principal had to incur agency costs. Costs charged to principals to encourage managers to maximize shareholder welfare and not prioritize their interests define as agency costs. The agency cost mechanism influences management flexibility in performing earnings management. Agency costs include the cost of building a corporate governance mechanism. These mechanisms involve monitoring managerial activities, auditing, and establishing organizational structures that can limit unexpected managerial behavior, such as the independent commissionaires and commissioner board. One mechanism that can suppress income smoothing practices is agency cost (An, $\mathrm{Li}, \& \mathrm{Yu}, 2016)$. If the mechanism works effectively, the influence of these variables on income smoothing should be negative. Board size refers to the board size of the company. The board's role could improve earnings quality by limiting earnings management level through the supervisory function of financial reporting (Daghsni, Zouhayer, \& Mbarek, 2016; Holtz \& Sarlo Neto, 2014; Obigbemi, Omolehinwa, Mukoro, Ben-Caleb, \& Olusanmi, 2016). The board size influenced the supervisory process performed by the board. Omrani (2016) showed that large boards provide a better control environment and perfect performance. They found a positive influence between board size and financial reporting bias. The Board size decreased earnings management. A larger board size could be more effective at monitoring financial reporting effectively than smaller board sizes. Board size affected the low level of accruals, which could be assumed to play a significant supervisory role. A large board reflects the diversity of experience and can increase the effectiveness in suppressing earnings management actions. Vander Bauwhede and Willekens (2008) provided evidence of the role of board size in earnings management and found evidence that the degree of engineering reduces reported earnings and decreases with increasing board size. This empirical evidence supported that the larger the board will limit earnings management practices. The board size affected the oversight exercised (Omrani, 2016; Uwuigbe, Sunday, \& Oyeniyi, 2014). The more the board, the more the members' ability to supervise company operations would be more intensive. They had comprehensive experience and expertise. Adequate supervision of the board is an obstacle to income smoothing practices. Board size affected the tendency of income smoothing (Kustono \& Effendi, 2016; Manukaji, 2018). The board was responsible for monitoring the running of the company. The experience and knowledge of each member could improve the performance of the board. The larger the board size, the more useful to monitor management performance. Management's opportunity to practice earnings management decreased. Based on the empirical findings above, hypothesis 1 is the commissioner board size suppresses the income smoothing tendency.

\subsection{Independent Commissioner's Size}

According to the Indonesian Stock Exchange regulations, an independent commissionaire is a board member who is not affiliated with the controlling shareholder, other directors, or commissioners of the company concerned. Due to the prevailing regulations, he could not hold concurrent positions as a director in another company's affiliates. This position requires competence and an indepth understanding of the laws and regulations in the capital market. The need for the credibility of financial statements encourages the emergency of independent commissionaires. Several previous studies have shown that effective governance, reliability of financial statements, and firm performance increase with the presence of independent commissionaires ((Liu, Harris, \& Omar, 2013; Nuryana \& Surjandari, 2019). Busirin, Azmi, and Zakaria (2015) examined the effect of the board and earnings management's supervisory role. They used the proportion of independent commissionaires as one of the dimensions of the effectiveness of board supervision. The results showed a significant negative effect. This conclusion supported that the independent commissionaires effectively maintained the financial reporting system. The board with the independent commissionaire majority was more able to apply corporate governance standards. Independent commissionaires carry out a supervisory function in public companies. The effect of its existence will have a negative impact on opportunistic management behavior if the independent commissionaires' action is effective (Al Azeez, Sukoharsono, Roekhudin, \& Andayani, 2019; Alves, 2014; X. Chen, Cheng, \& Wang, 2015). However, if the commissioners cannot work effectively, this will not affect management behavior (Mohd Fadzilah, 2017; Shaique, Guo, Shaikh, Khan, \& Usman, 2017). Based on the empirical findings above, hypothesis 2 is the independent commissioner's size suppresses the income smoothing tendency.

\subsection{Audit Quality}

Audit quality includes the auditor's competence in auditing financial statements independently to increase the credibility of financial statements, reduce material misstatements, and give users confidence in their opinions. This definition indicates that the auditor must be competent, independent, and objective. The results of the audited report must be credible and free from material misstatement. Accurate decision making should use reasonable opinions issued. An auditor was an external party who guaranteed the credibility of the company's financial statements by conducting systematic testing to determine the financial statements' fairness (Handoko, Mulyawan, \& Tanuwijaya, 2020; Yang et al., 2017). An essential role of the external auditor was to audit the client's financial statements. This process assured shareholders, potential investors, and creditors that the balance sheet and income statement accurately reflected the client's activities. The audit's function was to reduce information asymmetry and control problems caused by sharing ownership and management. The identification of audit quality is a complicated issue. Audit quality research primarily focuses on the big four auditor groups as a proxy for high audit quality. Apart from this dichotomy, another proxy is the length of audit tenure. The longer the tenure, the better the auditor was considered to have the client company's ability 
and understanding (El Guindy \& Basuony, 2018; Mohammed Al-Shetwi, 2011; Reguera-Alvarado et al., 2019; Tyokoso, Sabari, Dogarawa, \& Ibrahim, 2019). To carry out the audit properly, the auditor needed to understand the client's operations, accounting system, and control environment so that the auditor could detect and find material misstatements. A lack of understanding of the client's business processes reduced the auditor's ability to detect material errors. Reguera-Alvarado et al. (2019) concluded that a longer audit tenure might limit managerial discretion concerning accounting accruals. This finding implied a higher audit quality. The longer the client relationship, the auditor gave the auditor the ability to understand management behavior and become more independent. Abata and Migiro (2016) found that creditors have more confidence in better audit quality as the audit period increases. (Fawzi, 2015) showed the same result. It analyzed the perceptions of financial statement users on audit quality. Investors felt a rise in quality due to an increase in audit tenure. Auditor rotation reduces the effectiveness of the audit. The new auditor should start with the initial stage of studying his client's business processes. In this condition, it is easier for companies to do revenue engineering. Audit problems arise with new auditors because they have little information about the company. Firms with shorter audit tenure have larger accruals and lower persistence. Experience is the accumulation of knowledge that can improve the skills and abilities of auditors. The longer the audit tenure impacts his ability to detect income smoothing efforts. In this study, the hypothesis proposed is: audit tenure affects the tendency to smooth income. The audit quality affected the income smoothing trend (Fawzi, 2015; Laily, 2017; Mansor, Che-Ahmad, Ahmad-Zaluki, \& Osman, 2013). The experience will increase knowledge and skills - the more experienced the auditor, the better quality and competence. An auditor who audits the same company for several periods understands the condition of the client company. This ability makes auditors better able to recognize earnings management carried out by management. The existence of auditors with long tenure will reduce the opportunities for the company to smooth income. Based on the empirical findings above, hypothesis 3 is the audit tenure suppresses the income smoothing tendency.

\section{Methodology}

This study is explanatory research, which aims to explain the causal relationship between variables through hypothesis testing. Design this study to identify cause and effect relationships between variables. The data used is secondary data. This study's data are financial report data of December 31, 2009 - 2018 of Indonesia's public manufacturing companies. The Indonesian Capital Market Directory is the data source.

\subsection{Population and Sample}

According to the research objectives, the population is a public manufacturing company in Indonesia with accessible and available data. The classifications of companies that are the population of this study are as follows: (1) registered consecutively as a public company from 2008 to 2018, (2) It did not change the business form. Companies have positive equity at the beginning of the period, and (3) presented financial statements in the rupiah currency. The number of manufacturing companies in 2009 was 126 companies. Data increased to 233 in 2018. Analysis of the population adequacy criteria shows companies that meet the requirements are 106 firms. Hypothesis testing using 742 firm years-data from 2012 to 2018. When combined with the index calculation data using data starting from 2009, the number reaches 1,060 firm-years. The variables are (1) the dependent variable is the income smoothing tendencies; (2) independent variables which include variable board size, independent commissionaires' size, and audit tenure; and (3) control variables include firm size, debt, institutional ownership, and firm value.

\subsection{Income Smoothing Tendency}

A ratio scale using the accrual correlation formula (Kustono, 2011) use to measure income smoothing tendency. If the index number for three consecutive periods shows a value of 1 or less, the company is doing income smoothing. The calculation of the accrual correlation index (PP) is with the following steps:

$$
\text { PPit }=a b s[\{(\mathrm{Si}-\mathrm{Si}-\mathrm{t}) / \mathrm{Si}-\mathrm{t})\} /\{(\mathrm{Li}-\mathrm{Li}-\mathrm{t}) / \mathrm{Li}-\mathrm{t}\}]
$$

$\mathrm{PP}$ is the income smoothing index.

$\mathrm{L}$ is reported profit / reported net income

$\mathrm{S}$ is Sales

$i$ is firm $i$

$t$ is period $t$

To determine the coefficient of variation is calculated in the previous three years observation period. In this study, the objectives of income smoothing include operating profit and net income. Companies are classified as smoothing if at least four periods (two ratios PP) have successive absolute index below 0.5. Income smoothing is the practice of earnings manipulation that occurred in some periods. The number of commissioner boards is board size measurement. independent commissionaires size is measured by the ratio of independent commissionaires to the board size. Audit tenure is the number of annual periods the auditor performs audits on a particular client. The audit tenure is the number of times the auditors conducted annual audits of the observation company during 2009-2018. This study's data analysis consists of a descriptive analysis to describe the population's characteristics 
and support hypothesis testing. To test the hypothesis is done using binary logistic regression. Logistic regression using the Maximum likelihood. The goodness of fit model testing uses Hosmer and Lemeshow tests. It is said to fit if there is no significant difference between the model and the observed value. The binary logistic regression assumptions must be dichotomous dependent variables, exclusive between the independent variables, and a large sample. The overall model tested is 4 (four) models: models I, II, III, and IV. Each of these models is as follows.

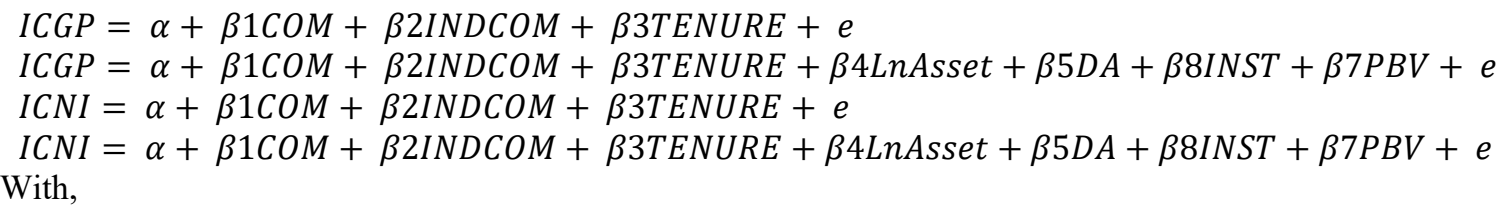

With,

ICGP is income smoothing with gross profit as smoothing object

ICNI is income smoothing with net income as a smoothing object

$\mathrm{COM}$ is the commissioner board size;

INCOM is an independent commissioner's size;

TENURE is audit tenure;

LnAsset is firm size;

$\mathrm{D} / \mathrm{A}$ is debt to asset ratio;

INST is an institutional investor;

$\mathrm{PBV}$ is firm value;

All data processed comes from the company's audited financial statements for the 2009-2018 period. The income smoothing index calculation uses five years of data. The determination of the 2012 income smoothing index uses data from 2009 - 2012. Hypothesis testing uses data from 2012 - 2018, totaling 742 company years. When combined with the index calculation data using data starting from 2009, the number reaches 1,060 firm-years. Table 1 shows the results of the descriptive analysis of all variables.

Table 1

Descriptive Statistics

\begin{tabular}{|c|c|c|c|c|}
\hline & Minimum & Maximum & Mean & Std. Deviation \\
\hline LnAsset & 24.48 & 31.66 & 27.3544 & 1.42350 \\
\hline $\mathrm{D} / \mathrm{A}$ & 0.15 & 0.99 & 0.5314 & 0.212421 \\
\hline COM & 2 & 11 & 4.36 & 1.764 \\
\hline INDCOM & 1 & 4 & 1.49 & 0.729 \\
\hline TENURE & 1 & 5 & 3.55 & 1.643 \\
\hline PBV & 0.12 & 21.76 & 1.9156 & 3.3501 \\
\hline INST & 0 & 81 & 9.95 & 16.967 \\
\hline ICGP & 0 & 1 & 0.69 & 0.462 \\
\hline ICNI & 0 & 1 & 0.78 & 0.417 \\
\hline
\end{tabular}

The log natural total assets presented in financial statements is firm size measurement. This transformation aims to facilitate data fluctuation. Table 1 shows the firm's asset size in the range between 8.3 and 16.6, with a mean of 13.5. The observational data show an even distribution because the mean approaches the median of 13.395. The ratio of debt to assets is a measurement of the debt variable. Descriptive statistics for the variable debt, which is proxied by the total debt ratio to total assets, show a range of 0.09 and 1.11. The observed companies have a total debt ratio to total assets starting from 0.09 , with total debt exceeding total assets (1.11). This ratio's average value is 0.52 , which means it is around the median (0.53). The data for these variables are well distributed. The percentage of total institutional ownership measures institutional ownership following institutional limits compared to the total shares outstanding in financial statements. Descriptive statistics show a mean ratio between 0.00 and 80.00 . The rate of institutional ownership shows results that do not reflect the quality of good corporate governance. High institutional ownership is assumed to improve the quality of company management. The average observation company has an 11.9 percentage of institutional ownership. In general, the average percentage of institutional ownership is deficient. The number of the commissioner is a measurement of board size. The descriptive statistics in Table 1 show that board sizes range from 2 to 10 with a mean of 4.48. The mean of this variable observation data offers the closeness to the median point (4.00). Independent commissionaire's size variable is measured based on the percentage of commissioners classified as independent from all commissioners. The average of independent commissionaires' size shows a range between 0.00 and 0.67 . The low mean ratio is 0.258. This figure shows that in the observation firm, the mean of independent commissionaire's size is a minority compared to the number of board members. There is an impression that the company does consider the independent commissionaires positively, 
so the proportion is deficient. From the classification results of smoothers and non-smoothers based on the accrual correlation (2011), operating income (gross profit) is the most preferred object to be smoothed. There are $30.2 \%$ that perform income smoothing. There are $21.7 \%$ who have performed income smoothing on their net income objects.

\section{Empirical Results and Discussion}

Researchers used the Omnibus Test to test the goodness of fit test. The result is shown in Table 2. Chi-square value 17.289> Chi-square table and a significance of 0.001 so that it rejected $\mathrm{H} 0$. The addition of independent variables could affect the model. In other words, the model was declared fit.

Table 2

Omnibus Tests of Model Coefficients

\begin{tabular}{lccc}
\hline & Chi-square & df & Sig. \\
\hline Step & 17.289 & 3 & .001 \\
Block & 17.289 & 3 & .001 \\
Model & 17.289 & 3 & .001 \\
\hline
\end{tabular}

Source: own 2020

Hypothesis 1 to hypothesis 4 is tested using the binary logit regression technique with the SPSS version 25 . The income statement of public manufacturing companies contains profit classifications, namely operating income (gross profit) and net income. The income smoothing test is carried out on two smoothing objects. The equations in models 1 and 2 use operating profit as an income smoothing object, and models 3 and 4 use net income as an income smoothing object.

Table 3

Variables in the Equation: Model 1 and 2

\begin{tabular}{|c|c|c|c|c|c|c|}
\hline & \multicolumn{3}{|c|}{ Model 1} & \multicolumn{3}{|c|}{ Model 2} \\
\hline & $\mathrm{B}$ & Sig. & $\operatorname{Exp}(B)$ & $\mathrm{B}$ & Sig. & $\operatorname{Exp}(B)$ \\
\hline COM & -0.507 & $0.010 * *$ & 0.602 & -0.592 & $0.003 * *$ & 0.553 \\
\hline INDCOM & 1.277 & $0.027 *$ & 3.585 & 1.497 & $0.010 * *$ & 4.469 \\
\hline TENURE & 0.176 & $0.000 * *$ & 1.193 & 0.170 & $0.001 * *$ & 1.185 \\
\hline $\mathrm{D} / \mathrm{A}$ & & & & -1.885 & $0.000 * *$ & 0.152 \\
\hline INST & & & & -0.011 & $0.033 *$ & 0.989 \\
\hline PBV & & & & -0.031 & 0.220 & 0.970 \\
\hline LnAsset & & & & 0.020 & 0.767 & 1.020 \\
\hline Constant & 2.427 & 0.016 & 11.323 & 3.731 & 0.054 & 41.725 \\
\hline Nagelkerke R Square & 0.039 & & & 0.101 & & \\
\hline
\end{tabular}

** sig. $0.01 ; * \operatorname{sig} 0.05$

COM is the commissioner board size; INCOM is independent commissioner's size; TENURE is audit tenure; D/A is debt to asset ratio; INST is an institutional investor; PBV is firm value; LnAsset is firm size; ICGP is income smoothing with gross profit as object smoothing; ICNI is income smoothing with net income as object smoothing

Source: own 2020

According to equation 3, all independent variables in models 1 and 2 have a $\mathrm{P}$-value ( $\mathrm{Sig})<0.05$. The variables board size, independent commissionaires' size, and audit tenure have a significant income smoothing possibility. The board size variable has the potential for income smoothing. The relationship between the two variables is positive. The higher the board size, the higher the chance of income smoothing practice. The variables independent, commissionaire's size and audit tenure, show a negative effect. The higher the value of the two variables, the smaller the chance of income smoothing practice. The control variable related to income smoothing is debt. The variables of institutional ownership, firm value and firm size are not associated with the probability of income smoothing. The amount of opportunity is indicated by the EXP value (B) or the odds ratio. A high odds ratio suggests that this variable has a high effect on differences in respondent selection. The independent variable that has the most opportunity to suppress income smoothing is the independent commissionaires' size of 3,585. This opportunity increased to 4,469 when the model includes control variables. The audit tenure has 1,193 opportunities to reduce income smoothing. The probability drops to 1.185 when control variables are entered into the model. The Nagelkerke R square values in models 3 and 4 are 0.0390 and 0.101 . The independent variable's ability to explain the dependent variable was $3.9 \%$ and increased to $10.1 \%$ when the test includes the control variables. Based on the equation table, all independent variables in Models 1 and 2 have a P-value (Sig) $<0.05$. The board size, independent commissionaires' size, and audit tenure have a significant possibility of income smoothing. Control variables show a relationship with income smoothing. Debt and institutional ownership affect income smoothing. In contrast, firm size and firm value variables are not related to the possibility of income smoothing on net income. In line with model 1 and model 2, Table 4 shows the independent variable with the most opportunity to suppress income smoothing is the independent commissionaire's size of 4,467. This opportunity increased to 4,893 when the control variables were included in the research 
model. The audit tenure has 1.240 opportunities to reduce income smoothing. This probability drops to 1.225 when the control variables are entered into the model.

Table 4

Variables in the Equation: Model 3 and 4

\begin{tabular}{|c|c|c|c|c|c|c|}
\hline (2) & \multicolumn{3}{|c|}{ Model 3} & \multicolumn{3}{|c|}{ Model 4} \\
\hline INCOM & 1.497 & $0.021 *$ & 4.467 & 1.588 & $0.017^{*}$ & 4.893 \\
\hline TENURE & 0.215 & $0.000 *$ & 1.240 & 0.203 & 0.000 ** & 1.225 \\
\hline $\mathrm{D} / \mathrm{A}$ & & & & 0.076 & 0.865 & 1.079 \\
\hline INST & & & & -0.007 & 0.182 & 0.993 \\
\hline PBV & & & & -0.034 & 0.183 & 0.966 \\
\hline
\end{tabular}

** sig. 0.01; * sig 0.05

COM is the commissioner board size; INCOM is independent commissioners' size; TENURE is audit tenure; D/A is debt to asset ratio; INST is an institutional investor; PBV is firm value; LnAsset is firm size; ICGP is income smoothing with gross profit as object smoothing; ICNI is income smoothing with net income as object smoothing

The commissioner's size variable has the opportunity for income smoothing to occur. The relationship between the two variables is positive. The higher the commissioner's size, the higher the chance of income smoothing practice. The Nagelkerke R square values in models 3 and 4 are 0.046 and 0.06 . The independent variable's ability to explain the dependent variable was $4.6 \%$ and increased to $6 \%$ when the model includes the control variables. Based on testing models 1, 2, 3, and 4, as shown in Table 3 and Table 4, the following hypothesis testing results are obtained. Board size is positively related to income smoothing tendency. The findings of this study reject hypothesis 1 . Hypothesis 1 states that board size suppresses income smoothing tendencies. Independent commissionaire size reduces the income smoothing tendency. The findings of this study accept hypothesis 2 . independent commissionaire size suppresses income smoothing tendencies. The audit tenure significantly reduces the income smoothing. The results of this study accept hypothesis 3 . The control variable that shows the relationship with differences in income smoothing is debt in smoothing operating income (gross profit). If the smoothing object is net income, all control variables are proven not to affect the practice's probability.

\subsection{Discussion}

This study aims to prove the factors that suppress income smoothing. There are two objects of income smoothing, namely operating profit and net income. All of the tests did not give different results. The income smoothing object test is operating profit (models 1 and 2), showing that the independent commissionaire's size and audit tenure variables negatively affect income smoothing, likewise, in model 3 and model 4. In contrast to the hypothesis, the board size encourages income smoothing action. Board size has a significant positive effect on income smoothing tendency. An increase in the board size that cannot analyze financial statements will negatively impact financial statements' manipulation. The board's appointment procedures sometimes do not meet the requirements of transparency, accountability, responsiveness, independence, and fairness. A person's selection to become a board member often does not pay attention to aspects of expertise, knowledge, and experience following its characteristics. As a result, the board's addition does not suppress management's efforts to smooth income. The board is often more passive, does not effectively perform its supervisory function, and always supports the commissionaire board policies. Due to the characteristics of the company's highly concentrated ownership structure in Indonesia, the board's performance is also dominated by management power and the majority shareholder. Companies in Indonesia with small public ownership tend to have a high percentage of institutional ownership, and vice versa. In a concentrated company, the role of the board is no longer influential. The greater the board size, the more likely the company will do income smoothing. The board has increasingly failed to limit income smoothing. The larger the board's members, the more difficult it is to communicate and thus fail to qualify income smoothing efforts. The results support (Koevoets, 2017; Mahrani \& Soewarno, 2018). Koevoets (2017) found a positive influence between board size and earnings management. Large board sizes reduce the effectiveness of monitoring, as coordination becomes more difficult. The larger the board size will cause communication and coordination difficulties. This opinion follows (Mahrani \& Soewarno, 2018), which stated that the board's composition and structure are the impression of the board's role. Board size can reduce accounting engineering opportunities if it is supported by good board composition and structure. Based on the analysis of the research results presented, this study's finding is that the board size is not proven to reduce income smoothing practice opportunities. The test results in Table 3 show that increasing independent commissionaires size reduces income smoothing practices. Companies that have minority independent commissionaires tend to have higher earnings management. In conclusion, most independent commissionaires' actions could translate into more effective monitoring. Independent commissionaires have a positive contribution to oversight responsibilities. The high proportion of independent commissionaires' size is proven to limit the company's income smoothing. There are several explanations for this. First, independent commissionaires are members of the 
board with the competence to work objectively. They shouldn't have any associations with companies or company executives. Generally, they are selected and appointed because they have the capability of corporate governance. The combination of ability and independence makes supervision of management more effective. Management is not free to manipulate earnings reports. Second, independent commissionaires have independence, so they uphold integrity. Independent relates to an objective and independent mental attitude. The members can work independently and objectively to suppress the management's efforts to implement earnings management. Third, income smoothing is a management engineering action in the long term (several periods). The more the income measure, the more effective it is in monitoring income smoothing behavior because of a more comprehensive capability. The result supports the previous research (Ahmad, Abdullah, Jamel, \& Omar, 2015; Busirin et al., 2015; Kapoor \& Goel, 2019; Uwuigbe et al., 2014). The greater the sizes, the more representative the interests of shareholders. INCOM existence will reduce opportunistic motivation to do income smoothing. This study's results differ from (Idris, Abu Siam, \& Nassar, 2018; Luo \& Jeyaraj, 2019; Nuryana \& Surjandari, 2019). They found a differential effect of independent commissionaires' size on earnings management. In a study of earnings management, it is not the board's independence that is important for engineering but its quality. (Susanto \& Pradipta, 2016) suspected that the board size is ineffective because certain groups dominate the board, and independent members do not understand its problems. Based on the research results analysis, the findings obtained from this study are that the size of independent commissioners suppresses income smoothing. Result testing presented in Table 3 and Table 4 finds that audit tenure suppresses income smoothing in Indonesia's public manufacturing companies. The seventh hypothesis states that tenure auditors reduce the income smoothing tendency to be accepted from the test results. The long audit tenure increases the experience and knowledge of the auditor about the client. Better understanding will undoubtedly affect the accuracy of the audit results. Auditors find it easier to detect earnings management carried out by management. The study's findings align with the research of El Guindy and Basuony (2018) and Mohamed and Habib (2013). Auditors who had a long working period in auditing a company had more experience and knowledge about its condition. The more experienced an auditor was, the more capable and better performance in increasingly complex tasks. The audit experience played a role in determining the decisions. The more experienced, the more auditors would avoid making decisions. An inexperienced auditor had a more significant error rate than a more experienced auditor. El Guindy and Basuony (2018) found that experience reduces the impact of irrelevant information on auditor judgment. Experienced auditors are not affected by the presence of irrelevant information in making decisions. Shorter audit periods generally left larger accruals in firms. They concluded that the longer the audit tenure, the more able to limit earnings management by accounting accruals. This finding supports better audit quality. Mohamed and Habib (2013) found evidence that capital market players see high tenure auditors as having more satisfying audit quality. The method used by Mayangsari is to measure investors' perceptions of audit quality based on audit tenure. This finding contradicts (Lestari \& Aeni, 2019; Reguera-Alvarado et al., 2019; Tyokoso et al., 2019). They concluded that when the audit tenure increases, clients will have more opportunities to manipulate financial statements and adjust them to financial statements' forecasts. A good relationship between the client and the auditor provides an opportunity for a decrease in objectivity. Earning management, which is classified as income smoothing, is an attempt to manage earnings management over several periods. The long audit tenure provides the auditor's ability to observe this technique that the short-term auditor could not. Based on the research results analysis, the theoretical findings obtained from this study are that audit tenure has a negative and significant effect on income smoothing.

\section{Conclusion and Limitations}

\subsection{Conclusion}

Based on the analysis of the research results and the discussion previously described, the conclusions in this study are as follows. Board size has a positive effect on the tendency of income smoothing. Hypothesis 1, which states that board size suppresses the income smoothing tendency, is not accepted. This conclusion indicates that the board size is not an appropriate measure of the effectiveness of supervision. The board size encourages the practice of income smoothing. In Indonesia, the public held a small number of shares. Its effect on the board's ineffective function. Insiders still dominate share ownership in Indonesia. This condition indicates owners' and managers' domination so that the board's role is often less significant. Independent commissionaires size reduces income smoothing tendency. The second hypothesis, which states that independent commissionaires size suppresses income smoothing in public manufacturing companies in Indonesia, is accepted. This conclusion suggests that independent commissionaires are monitoring mechanism for reducing agency conflicts. Increasing the independent commissionaire's size will improve supervision quality and reduce management opportunities to manipulate financial reports. Audit tenure has a significant negative effect on income smoothing trends. The third hypothesis states that audit tenure negatively influences the income smoothing tendency of public non-financial companies in Indonesia to be accepted. The test results show that the more audit period is directly proportional to the auditor's ability to limit income smoothing. Audit tenure can be a proxy for audit quality. These findings strengthen the auditors as a monitoring mechanism to reduce agency problems.

\subsection{Limitations and suggestions}

This study has limitations that are an integral part of the overall research. This limitation is expected to be a reference and have implications for the improvement of further research. Some of the limitations of this study are as follows. Some variables were 
not supported by fair data distribution (audit tenure, institutional ownership, and independent commissioner). Future research should improve data distribution to avoid inference bias. Testing the audit quality variables, the board size, and independent commissionaires size used only quantitative measures. The measurement does not enter individual personality nuances, intellectual abilities, competence, and experience in this study. Future research can deepen the qualitative aspects of the individual to strengthen conclusions. Measurement of income smoothing tendency used the accrual correlation formula (Kustono, 2011). This index might not entirely reflect averaging behavior. Future research needs to compare this formula with other measurement models, such as the classification model, the accrual model, or the profit comparison model before and after changes. This study did not classify the company's industrial sector as one factor influencing its accounting policies. This action could lead to inaccurate conclusions due to the uncontrolled industrial sector. Future research needs to consider industrial sector variables as control variables.

\section{References}

Abata, M. A., \& Migiro, S. O. (2016). Corporate governance and management of earnings: Empirical evidence from selected Nigerian-listed companies. Investment Management and Financial Innovations, 13(2), 189-205.

Ahmad, R. A. R., Abdullah, N., Jamel, N. E. S. M., \& Omar, N. (2015). Board and risk management and internal control disclosure level: Evidence from Malaysia. Procedia Economics and Finance, 31(2011), 601-610.

Al-Natsheh, N., \& Al-Okdeh, S. (2020). The impact of creative accounting methods on earnings per share. Management Science Letters, 10(4), $831-840$.

Al Azeez, H. A. R., Sukoharsono, E. G., Roekhudin, \& Andayani, W. (2019). The impact of board characteristics on earnings management in the international Oil and Gas Corporations. Academy of Accounting and Financial Studies Journal, 23(1), 1-26.

Alves, S. (2014). The Effect of Board Independence on the Earnings Quality: Evidence from Portuguese Listed Companies. Australasian Accounting, Business and Finance Journal, 8, 23-44. https://doi.org/10.14453/aabfj.v8i3.3

An, Z., Li, D., \& Yu, J. (2016). Earnings management, capital structure, and the role of institutional environments. Journal of Banking and Finance, 68, 131-152. https://doi.org/10.1016/j.jbankfin.2016.02.007

Bressan, V. G. F., de Souza, D. C., \& Bressan, A. A. (2017). Income smoothing: Um estudo das cooperativas de crédito do setor de saúde. Revista Brasileira de Gestao de Negocios, 19(66), 627-643. https://doi.org/10.7819/rbgn.v0i0.2617

Busirin, M. F., Azmi, N. A., \& Zakaria, N. B. (2015). How effective is board independence to the monitoring of earnings manipulation? Procedia Economics and Finance, 31(15), 462-469. https://doi.org/10.1016/s2212-5671(15)01177-6

Chen, C., Weng, P., \& Fan, H. (2016). Institutional ownership, income smoothing and the value-relevance of accounting numbers. Management Review, 35(Jul), 109-134. https://doi.org/10.6656/MR.2016.35.3.ENG.109

Chen, X., Cheng, Q., \& Wang, X. (2015). Does increased board independence reduce earnings management? Evidence from recent regulatory reforms. Review of Accounting Studies, 20(2), 899-933. https://doi.org/10.1007/s11142-015-9316-0

Curvello, R. da S. S., Rodrigues, A., \& Macedo, M. A. da S. (2018). Loss reserve error in the Brazilian insurance market: Empirical evidence of the response to economic and tax regulations. Revista Brasileira de Gestao de Negocios, 20(4), 550-572.

Dadbeh, F., \& Mogharebi, N. (2013). A study on effect of information asymmetry on earning management: Evidence from Tehran Stock Exchange. Management Science Letters, 3(7), 2166-2166. https://doi.org/10.5267/j.msl.2013.06.001

Daghsni, O., Zouhayer, M., \& Mbarek, K. B. H. (2016). Earnings fanagement and board characteristics: Evidence from French listed Firms. Arabian Journal of Business and Management Review, 6(5), 1-9. https://doi.org/10.4172/2223-5833.1000249

El Guindy, M., \& Basuony, M. (2018). Audit Firm Tenure And Earnings Management: The Impact Of Changing Accounting Standards In UK Firms. The Journal of Developing Areas, 52, 167-181. https://doi.org/10.1353/jda.2018.0058

Farichah, F. (2017). Relationship of earnings management and earnings quality before and after IFRS implementation in Indonesia. European Research Studies Journal, 20(4), 70-81. https://doi.org/10.35808/ersj/875

Fawzi, S. M. (2015). The impact of income smoothing on earnings quality in emerging markets: Evidence from GCC markets. Journal of Accounting in Emerging Economies, 5(3), 299-324. https://doi.org/10.1108/JAEE-04-2011-0011

Handoko, B. L., Mulyawan, A. N., \& Tanuwijaya, J. (2020). Big Data in Auditing for the Future of Data Driven Fraud Detection. International Journal of Innovative Technology and Exploring Engineering, 9(3), 2902-2907.

Holtz, L., \& Sarlo Neto, A. (2014). Effects of board of directors' characteristics on the quality of accounting information in Brazil. Revista Contabilidade \& Finanças, 25(66), 255-266. https://doi.org/10.1590/1808-057x201412010

Idris, M., Abu Siam, Y., \& Nassar, M. (2018). Board independence, earnings management, and the moderating effect of family ownership in Jordan. Management and Marketing, 13(2), 985-994. https://doi.org/10.2478/mmcks-2018-0017

Junianto, A., \& Wisadha, I. G. S. (2014). Pengaruh Firm Size, Financial Leverage, dan Institutional Ownership pada Praktik Income Smoothing. E-Jurnal Akuntansi, 7(3).

Kapoor, N., \& Goel, S. (2019). Do diligent independent directors restrain earnings management practices? Indian lessons for the global world. Asian Journal of Accounting Research, 4(1), 52-69. https://doi.org/10.1108/ajar-10-2018-0039

Koevoets, S. (2017). Board characteristics and earnings quality: Evidence from the USA. Erasmus Universitieit Rotterdam.

Kustono, A. S. (2011). The theoretical construction of Income Smoothing Measurenment. Journal of Economics, Business and Accountancy Ventura, 14(1), 59-78.

Kustono, A. S., \& Effendi, R. (2016). Earnings Management and Corporate Governance Case in Indonesia. Advanced Science Letters, 22(12), 4345-4347. https://doi.org/https://doi.org/10.1166/asl.2016.8147

Kustono, A. S., \& Valencia, Z. G. (2017). How the effectiveness knowledge sharing affect enterprise resource planning system case in East Java-Indonesia. Advanced Science Letters, 23(5), 4295-4297. https://doi.org/10.1166/asl.2017.8263

Laily, N. (2017). The effects of good corporate governance and audit quality on earnings management. Journal of Accounting and Business 
Education, 1(1), 134. https://doi.org/10.26675/jabe.v1i1.9754

Lestari, N., \& Aeni, N. (2019). The Effect of Audit Quality And Earnings Management On Firm Performance. https://doi.org/10.2991/icaess19.2019.7

Linhares, F. S., Da Costa, F. M., \& Beiruth, A. X. (2018). Gerenciamento de resultados e eficiência de investimentos. Revista Brasileira de Gestao de Negocios, 20(2), 295-310. https://doi.org/10.7819/rbgn.v20i2.3180

Liu, J., Harris, K., \& Omar, N. (2013). Board committees and earnings management. Corporate Board: Role, Duties, and Composition, 9(1), 617. https://doi.org/10.22495/cbv9i1art1

Luo, J., \& Jeyaraj, S. s. (2019). Board characteristics and earnings management: Empirical analysis of UK listed companies. European Journal of Accounting, Auditing and Finance Research, 7(5), 27-54.

Mahrani, M., \& Soewarno, N. (2018). The effect of good corporate governance mechanism and corporate social responsibility on financial performance with earnings management as a mediating variable. Asian Journal of Accounting Research, 3(1), 41-60.

Mansor, N., Che-Ahmad, A., Ahmad-Zaluki, N. A., \& Osman, A. H. (2013). Corporate Governance and Earnings Management: A Study on the Malaysian Family and Non-family Owned PLCs. Procedia Economics and Finance, 7(Icebr), 221-229.

Manukaji, I. J. (2018). Corporate Governance and Income Smoothing in the Nigerian Deposit Money Banks. International Journal of Business \& Law Research, 6(1), 27-38.

Maswadeh, S. (2018). The effect of the ownership structure on earnings management practices. Investment Management and Financial Innovations, 15(4), 48-60. https://doi.org/10.21511/imfi.15(4).2018.04

Mbobo, M. E., \& Archibong, E. C. (2016). Measuring the Quality of Financial Reporting: the Perception of Professional Accountants in Nigeria. International Journal of Innovative Research and Advanced Studies (IJIRAS), 3(7), 383-392.

Mohamed, D. M., \& Habib, M. H. (2013). Auditor independence, audit quality and the mandatory auditor rotation in Egypt. In Education, Business and Society: Contemporary Middle Eastern Issues (Vol. 6). https://doi.org/10.1108/EBS-07-2012-0035

Mohammed Al-Shetwi. (2011). Impact of internal audit function (IAF) on financial reporting quality (FRQ): Evidence from Saudi Arabia. African Journal of Business Management, 5(27), 11189-11198. https://doi.org/10.5897/ajbm11.1805

Mohd Fadzilah, N. S. (2017). Board of directors' characteristics and earnings management of family-owned companies. International Journal of Accounting \& Business Management, Vol. 5(No. 2), 68-83.

Nuryana, Y., \& Surjandari, D. A. (2019). The effect of good corporate governance, and earning management on company financial performance. Global Journal of Management and Business Research: Accounting and Auditing, 19(1), 26-39.

Obigbemi, I. F., Omolehinwa, E. O., Mukoro, D. O., Ben-Caleb, E., \& Olusanmi, O. A. (2016). Earnings management and board structure: Evidence from Nigeria. SAGE Open, 6(3). https://doi.org/10.1177/2158244016667992

Omrani, A. A. (2016). Evaluating the modifying effect of corporate governance on the relationship between free cash flow and earnings management of companies listed in Tehran Stock Exchange. International Journal of Humanities and Cultural Studies, Special Fe(1), 104118. Retrieved from http://www.ijhcs.com/index.php/ijhcs/index

Reguera-Alvarado, N., de Fuentes, P., \& Laffarga, J. (2019). Do auditors mitigate earnings management during economic crisis? Revista de Contabilidad-Spanish Accounting Review, 22(1), 6-20. https://doi.org/10.6018/rcsar.22.1.354271

Rusmin, R. (2014). Effects of audit quality, culture value, and firm' size on earnings reporting quality. Jurnal Akuntansi \& Auditing Indonesia, 18(1), 1-15. https://doi.org/10.20885/jaai.vol18.iss1.art1

Saksessia, D., \& Firmansyah, A. (2020). The role of corporate governance on earnings quality from positive accounting theory framework. International Journal of Scientific and Technology Research, 9(1), 808-820.

Shaique, M., Guo, F., Shaikh, R., Khan, S., \& Usman, M. (2017). Role of social relations of outside directors with CEO in earnings management. International Journal of Financial Studies, 5(4), 34. https://doi.org/10.3390/ijfs5040034

Shu, S. Q., \& Thomas, W. B. (2019). Managerial equity holdings and income smoothing incentives. Journal of Management Accounting Research, 31(1), 195-218. https://doi.org/10.2308/jmar-51822

Susanto, Y. K., \& Pradipta, A. (2016). Corporate governance and real earnings management. International Journal of Business, Economics and Law, 9(1), 17-23.

Toumeh, A. A., \& Yahya, S. (2019). A Review of Earnings Management Techniques : An IFRS Perspective. 11(3), 1-13.

Tyokoso, G. M., Sabari, M. H., Dogarawa, A. B., \& Ibrahim, H. (2019). Effect of Audit Quality on Earnings Management of Listed Oil Marketing Companies in Nigeria. SSRN Electronic Journal. https://doi.org/10.2139/ssrn.3492016

Uwuigbe, U., Sunday, D., \& Oyeniyi, A. (2014). The effects of corporate governance mechanisms on earnings management of listed firms in Nigeria Uwalomwa. Accounting and Management Information Systems, 13(1), 159-174.

Vander Bauwhede, H., \& Willekens, M. (2008). Disclosure on Corporate Governance in the European Union. Corporate Governance: An International Review, 16, 101-115. https://doi.org/10.1111/j.1467-8683.2008.00671.x

Wang, Z., \& Williams, T. (2011). Accounting Income Smoothing And Stockholder Wealth. Journal of Applied Business Research (JABR), 10, 96-104. https://doi.org/10.19030/jabr.v10i3.5929

Yang, C.-Y., Tan, B. L., \& Ding, X. (2017). Corporate governance and income smoothing in China. Journal of Financial Reporting and Accounting, 10(2), 120-139.

Young, S. (2015). Earnings Management and Corporate Governance. Wiley Encyclopedia of Management, 4(3), 1-5.

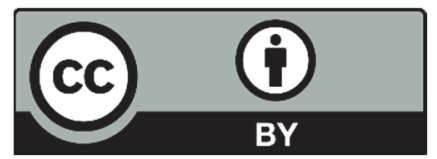

(C) 2021 by the authors; licensee Growing Science, Canada. This is an open access article distributed under the terms and conditions of the Creative Commons Attribution (CC-BY) license (http://creativecommons.org/licenses/by/4.0/). 